\title{
Variation in Xylem Hydraulic Structure and Function of Two Mangrove Species across a Latitudinal Gradient in Eastern Australia
}

\author{
Xin Jiang ${ }^{1,2,3}$, Brendan Choat ${ }^{3}$, Yong-Jiang Zhang ${ }^{4}\left(\mathbb{D}\right.$, Xin-Yi Guan ${ }^{1,2}$, Wen Shi ${ }^{5}$ and Kun-Fang Cao ${ }^{1,2, * \mathbb{C}}$ \\ 1 State Key Laboratory for Conservation and Utilization of Subtropical Agro-Bioresources, Guangxi University, \\ Nanning 530004, China; chiang.xin@foxmail.com (X.J.); xinyi.guan@uni-ulm.de (X.-Y.G.) \\ 2 Guangxi Key Laboratory of Forest Ecology and Conservation, College of Forestry, Guangxi University, \\ Nanning 530004, China \\ 3 Hawkesbury Institute for the Environment, Western Sydney University, Richmond, NSW 2753, Australia; \\ b.choat@westernsydney.edu.au \\ 4 School of Biology and Ecology, University of Marine, Orono, ME 04469, USA; yongjiang.zhang@maine.edu \\ 5 Department of International Cooperation and Exchange, Yunnan Agricultural University, \\ Kunming 650201, China; wing_shi@126.com \\ * Correspondence: kunfangcao@gxu.edu.cn
}

check for

updates

Citation: Jiang, X.; Choat, B.; Zhang, Y.-J.; Guan, X.-Y.; Shi, W.; Cao, K.-F.

Variation in Xylem Hydraulic

Structure and Function of Two

Mangrove Species across a

Latitudinal Gradient in Eastern

Australia. Water 2021, 13, 850.

https://doi.org/10.3390/w13060850

Academic Editor:

Adriana Bruggeman

Received: 28 February 2021

Accepted: 17 March 2021

Published: 19 March 2021

Publisher's Note: MDPI stays neutral with regard to jurisdictional claims in published maps and institutional affiliations.

Copyright: (c) 2021 by the authors. Licensee MDPI, Basel, Switzerland. This article is an open access article distributed under the terms and conditions of the Creative Commons Attribution (CC BY) license (https:/ / creativecommons.org/licenses/by/ $4.0 /$ )

\begin{abstract}
Mangroves growing in tropical and subtropical intertidal zones face challenges from warming and altered rainfall patterns associated with global climate change. Intraspecific variation in hydraulic traits may allow a mangrove species to acclimate to novel climatic conditions, yet little is known regarding the potential for adaptive plasticity in these traits. In this study, we aimed to quantify the variation in plant hydraulic traits of two widespread mangrove species growing across a latitudinal gradient. We investigated the xylem hydraulic structure and function of Avicennia marina and Aegiceras corniculatum, across three sites spanning a latitudinal gradient of $17.45^{\circ}$ in eastern Australia. We found that both species were highly resistant to xylem embolism and that there was significant intraspecific variation in hydraulic traits between sites. The highest embolism resistance and sapwood-specific hydraulic conductivity $\left(K_{\mathrm{S}}\right)$ were found at the lowest latitude site that had the highest mean annual temperature and precipitation. A. marina showed no differences in vessel size and density among sites. It has other special features such as successive cambia enhancing its ability to adapt to a large environmental gradient. In contrast, $A$. corniculatum showed higher vessel densities at lower latitudes. There was a significant and positive correlation $\left(R^{2}=0.72, p<0.05\right)$ between $K_{\mathrm{S}}$ and embolism resistance across species and sites, suggesting the absence of a tradeoff between hydraulic efficiency and safety. Both embolism resistance and $K_{\mathrm{S}}$ were negatively correlated with wood density but positively with vessel wall reinforcement. This study reveals that these two widespread mangrove species were adapted to warmer climates by enhancing both hydraulic efficiency and safety.
\end{abstract}

Keywords: xylem; hydraulics; latitudinal gradient; mangroves; anatomy; vulnerability to embolism

\section{Introduction}

Mangroves are a group of plants that grow in the coastal intertidal zones of tropical and subtropical regions from $27^{\circ} \mathrm{N}$ to $35^{\circ} \mathrm{S}$ [1-3]. They are strictly halophytic plants with high salt resistance [4-7]. Although mangroves grow in environments with plentiful water, they are constantly exposed to water stress because of the high osmotic pressure of the substrates in which they are rooted; high levels of xylem tension and high cellular osmotic pressures that are necessary for them to extract water from seawater and saline soils [3,8,9]. Thus, water absorption for mangroves is much more challenging than in typical soils, as a result of more negative water potentials of the soil pore water of saline habitats. Mangroves also experience high temperatures, high irradiance, and high atmospheric vapor pressure 
deficit (VPD), which lead to high transpirational demands and place additional pressure on their hydraulic system. However, it is unclear how far away mangroves are operating from water potentials leading to hydraulic failures (hydraulic safety margin) [10].

High tensile force (low water potentials) in the xylem due to the saline environment and strong transpiration under high VPD could bring a relatively high risk of cavitation (the development of air bubbles in xylem conduits) for mangrove species. Gas bubbles can spread from embolized vessels to sap-filled functional vessels through intervessel pit membranes, leading to hydraulic dysfunction $[3,11]$. As an adaptation to a high salinity environment, mangrove tree species are much more resistant to embolism than other tropical/subtropical terrestrial plants [12-14]. Mangroves usually have small xylem vessels which might be related to increased embolism resistance [14,15]. However, small vessels lead to relatively low hydraulic transportation efficiency according to the Hagen-Poiseuille equation, as hydraulic conductivity scales with the fourth power of vessel diameter [16]. This may form a tradeoff between hydraulic transportation efficiency and safety across mangrove species and habitats [17-19]. However, whether this tradeoff exists in mangroves, and whether they have some unique structural characteristics related to high embolism resistance, remain unclear.

Intraspecific variation of xylem functional traits across latitude has mainly been studied in temperate climate regions at high latitudes [20-26], while less attention has been paid to tropical and subtropical ranges [27-29]. Seasonal/annual average temperature and rainfall variations will impact xylem structure and function across/within species [21,30-33]. For instance, xylem vessel diameter was correlated with mean annual temperature and rainfall in angiosperm tree species across biomes in southwest China [34], as well as in a global analysis based on 2332 woody angiosperm species [35]. Vessel diameter is a strong determinant of hydraulic efficiency (sapwood-specific hydraulic conductivity, $K_{\mathrm{S}}$ ), and both vessel diameter and xylem hydraulic conductance tend to increase with ascending temperature in humid climates. Indeed, higher $K_{S}$ was found in habitats with higher temperatures and/or higher precipitation at the global scale [36]. Additionally, xylem hydraulic safety (embolism resistance, $\mathrm{P}_{50}$ ) was negatively correlated with mean annual rainfall $[10,37]$. Since temperature and rainfall tend to increase as latitudes decrease in eastern coastal areas of Australia, we might expect a variation in mangrove xylem structure, efficiency, and safety along latitudinal gradients, which could be quantified and used to infer their response to further warming.

Because temperature (especially winter air temperature) plays a fundamental role in the distribution of mangrove species $[15,38]$, mangroves could be sensitive to climate warming. Climate warming in averages and increasing extreme events like heatwaves can lead to additional challenges for mangrove plants [39]. A recent dieback event of $c .7400$ ha of mangrove forests was observed in the Gulf of Carpentaria, northern Australia [40], one of the largest mangrove distribution regions worldwide [41]. This catastrophic dieback might be related to an extreme weather event [40,42], including high temperatures (i.e., exacerbated evaporation), low rainfall (i.e., lacking freshwater), deficient storm winds (i.e., inactive air cooling), and a temporary sea-level fall (i.e., rising salinity of the sediments), caused by El Niño Southern Oscillation (ENSO). These factors likely resulted in the development of severe water stress that caused a catastrophic hydraulic dysfunction and consequently the mortality of mangroves. To understand the mechanisms that underlie the mangrove dieback and predict mangrove response to climate change, an understanding of their hydraulic safety margin across a latitudinal gradient is necessary.

Mangrove species with a wide latitudinal distribution provide a good opportunity to test their adaptive xylem variation over latitudes. The two widespread mangrove species, Avicennia marina (Verbenaceae) and Aegiceras corniculatum (Primulaceae), were chosen as the study materials due to their wide distribution [43]. Avicennia marina and Aegiceras corniculatum are not from the same family, but they are sympatric species in many sites. Both species are characterized by salt exclusion at the roots and salt secretion by leaf salt glands [3]. Avicennia marina is one of the most widespread and salinity-resistant mangrove 
species. The wide latitudinal range of its habitats has been related to its ability to survive, grow, and propagate across a series of environmental conditions, especially salinity and aridity $[4,5]$. Further, it can grow in the seaward position as well as in landward parts. As a common mangrove species, Aegiceras corniculatum occurs in tropical and subtropical coastal zones [43], and is most the distinctive of the mangrove forests due to its short and shrubby form.

In the present study, we examined variation in xylem hydraulic structure and function of these two mangrove species growing at three sites along a latitudinal gradient of $17.45^{\circ}$ in eastern Australia. The xylem anatomical structure, hydraulic conductivity, and resistance to embolism were measured. The sites become warmer and wetter with decreasing latitude. We expected increasing vessel size and hydraulic conductivity but lower embolism resistance towards a lower latitude. We aimed to address how these two common mangrove species differ in structure and hydraulic functioning in changeable environmental conditions. Due to high transpiration demand and high salinity of the habitats of mangroves, we hypothesized that both species will show high resistance to embolism, and a tradeoff would be observed between hydraulic efficiency and safety. These results will have implications for predicting the response of mangroves to climate change.

\section{Materials and Methods}

\subsection{Field Sites and Plant Materials}

The mangrove plants were collected in three sites along the eastern Australian coastline (Table 1). Five to six healthy, mature individuals for each species in each site were sampled from natural populations with similar height. The plant heights were $2.5-3.5 \mathrm{~m}$ for Avicennia marina, and 1.5-2 m for Aegiceras corniculatum, and slightly vary across the different sites at the population level. Hereafter, only the generic names are used to indicate the two species. The samples were collected at Marlow (in New South Wales) between July and August of 2017, as well as North Stradbroke Island (in Queensland) in June of 2017 and Cape Tribulation (in Queensland) between September and October of 2017. The laboratory measurements were conducted at the Hawkesbury Institute for the Environment (for the Marlow site, Western Sydney University), Moreton Bay Research Station (MBRS, for the North Stradbroke Island site, operated by the University of Queensland), and Daintree Rainforest Observatory (DRO, for the Cape Tribulation site, operated by James Cook University), to minimize sample transportation. Hereafter, Marlow, MBRS, and DRO are used to indicate the three sites. Based on the salinity map on the websites of Marine Science Australia and the Sea Surface Salinity Remote Sensing Project [44,45], these three sites have similar salinity levels at an average annual scale. We also collected seawater in Marlow and DRO for testing during the fieldwork on a rainless day. The electrical conductivity measurements showed consistent results among sites (data not shown). The data of mean annual temperature (MAT), seasonality of precipitation $\left(\mathrm{P}_{\mathrm{S}}\right.$; coefficient of variation across monthly measurements $\times 100$ ), and the minimum monthly precipitation of the year $\left(\mathrm{P}_{\min }\right)$ were obtained from WorldClim [46]; the aridity index (AI), mean annual precipitation (MAP), and potential evapotranspiration (PET) were acquired from Ecosystem Modeling and Scaling Infrastructure $[47,48]$ according to the coordinates of each site. The AI was defined as the ratio of annual potential evapotranspiration and mean annual precipitation (Table 1). The sampling time frame was during the relatively rainless and dry season, according to the weather information obtained from the nearest weather station for each site [49]. The monthly rainfall was $66.3 \mathrm{~mm}$ in August for Marlow; $61.4 \mathrm{~mm}$ in May 2017 for MBRS; $61.2 \mathrm{~mm}$ in September 2017 for DRO; the mean value of all years of data was used only for the Marlow site due to the absence of a designated record (station number: $066008,040537,031012$, respectively). Values of the month of the fieldwork were acquired, or values of the previous month were acquired if water potential measurement was carried out at the beginning of the month of fieldwork. 
Table 1. Meteorological information of sample sites including mean annual temperature (MAT; $\left.{ }^{\circ} \mathrm{C}\right)$, minimum monthly precipitation of the year $\left(\mathrm{P}_{\mathrm{min}} ; \mathrm{mm}\right)$, precipitation seasonality $\left(\mathrm{P}_{\mathrm{S}}\right.$; coefficient of variation, unitless) (data were downloaded from WorldClim [46]), mean annual precipitation (MAP; $\mathrm{mm}$ ), aridity index (AI; $\mathrm{mm} / \mathrm{mm}$ ), mean annual potential evapotranspiration (PET; mm) (data were downloaded from Ecosystem Modeling and Scaling Infrastructure [47]).

\begin{tabular}{cccccccc}
\hline Site & Coordinates & MAT & P $_{\min }$ & P $_{\text {S }}$ & MAP & AI & PET \\
\hline Marlow & $33^{\circ} 32^{\prime} 54^{\prime \prime} \mathrm{S}, 151^{\circ} 11^{\prime} 54^{\prime \prime} \mathrm{E}$ & 17.10 & 56 & 28.99 & 864.57 & 1.55 & 1338.85 \\
MBRS & $27^{\circ} 24^{\prime} 25^{\prime \prime} \mathrm{S}, 153^{\circ} 26^{\prime} 18^{\prime \prime} \mathrm{E}$ & 19.88 & 43 & 35.09 & 1200.01 & 1.24 & 1491.93 \\
DRO & $16^{\circ} 5^{\prime} 60^{\prime \prime} \mathrm{S}, 145^{\circ} 27^{\prime} 59^{\prime \prime} \mathrm{E}$ & 24.69 & 28 & 98.08 & 2920.08 & 0.54 & 1567.29 \\
\hline
\end{tabular}

Note. MBRS is the abbreviation of Moreton Bay Research Station, stand for the North Stradbroke Island site; DRO is the abbreviation of Daintree Rainforest Observatory, stand for the Cape Tribulation site.

\subsection{Maximum Vessel Length}

One sun-exposed, mature branch was collected, c. $1 \mathrm{~m}$ in length, from each tree and a total of three individuals were sampled per species per site, in the predawn. The maximum vessel length (MVL, $\mathrm{cm}$ ) was determined using a modified air-injection method [50-52]. The branches were flushed basipetally to decrease the possibility of overestimation of the MVL. The long branch segments were cut underwater and connected with silicon tubing (Cole-Parmer, Vernon Hills, IL, USA) and flushed for 2-3 h with degassed, filtered (filter capacity: $0.2 \mu \mathrm{m}$, Millipore, Burlington, MA, USA) solution of ultrapure water containing $2 \mathrm{mM} \mathrm{KCl}$ and $20 \mathrm{mM} \mathrm{NaCl}$ [15] at $0.15 \mathrm{MPa}$. A perfusing solution with similar ionic makeup and concentration to xylem sap minimizes the artifacts in conductivity measurements [53]. Then an air compressor pump or a syringe (when measuring in the field) was used to apply pressurized air at $0.1 \mathrm{MPa}$ through the distal ends while placing the basal ends underwater for 3-5 min at each step. Segments $1 \mathrm{~cm}$ long were cut off sequentially until a continuous stream of air bubbles was observed. The remaining length (from the injection point to the new cut) plus $0.5 \mathrm{~cm}$ was considered as the MVL.

\subsection{Stem Vulnerability Curve}

Stem xylem vulnerability to embolism was quantified using the bench dehydration method [54]. Five to six individual trees per species in each site were targeted from native populations with minimum human impacts. Branches of 1.5-1.7 $\mathrm{m}$ long (greater than fivefold of the MVL) from each tree were collected in the predawn. We used the updated protocol to assess the vulnerability $[55,56]$, avoiding the "cutting under tension" artifact. Harvesting the branch segments under xylem tension would introduce the risk that air would enter the xylem tissue even if the cuts were made underwater, thus the embolism would be overestimated. The targeted branches were recut immediately underwater to avoid artificial embolism. The cut end was bagged with a small plastic bag which contained moist paper towels and fastened by using a rubber band. Black plastic bags with moist paper towels inside were used to bag the branches separately and all the plant materials were transported to the laboratory as soon as possible. The ends of branches were cut again under water and kept immersed. All the branches were moved to a dark room for overnight rehydration.

The bagged branches were exposed to room temperature for equilibrium for at least $1 \mathrm{~h}$ and then taken out of the bags. Two healthy, fully expanded, mature leaves near the targeted segment were foiled and wrapped by using aluminum foil and plastic films. The branches were dried in a laboratory environment to reach different water potential ranges, and then were put in black plastic bags with humidified paper towels for at least $1 \mathrm{~h}$ to equilibrate to reach a homogeneity of water stress in the branches. Water potential $\left(\Psi_{\text {stem }}\right)$ of foiled, bagged leaves was measured using a Scholander-type pressure chamber (Model 1505D; PMS, Albany, OR, USA).

Once the $\Psi_{\text {stem }}$ was confirmed, the apical end of the target segment was cut underwater and rehydrated to release tension. After 20-30 min of rehydration, another cut was made at the proximal side to allow the whole segment to sit underwater. The segment was 
recut at both ends repeatedly until an unbranched segment 5-8 cm in length and 4-6 mm in diameter was obtained. Additionally, 5-10 min intervals between each cut were set for fully rehydration. The cut ends of all stem segments used for hydraulic measurements were at least $50 \mathrm{~cm}$ away (>MVL) from the initial cut ends underwater for rehydration. Both ends were trimmed with a fresh razor blade to obtain a clear and smooth cutting surface to avoid blockage caused by occluded vessel conduits.

The stem segment was connected to the hydraulic apparatus and a digital liquid flow meter (Liqui-Flow L13-AAD-11-K-10S; Bronkhorst, Ruurlo, Netherlands) was used to calculate the flow rate by pressure head $(0.003 \mathrm{MPa})$ which was generated by the gravity of a water column. Stem hydraulic conductivity was measured before and after stem flushing. The measuring solution and perfusing solution were the same as described above in Section 2.2. The segments were flushed with a pressure of $0.15 \mathrm{MPa}$ to remove air bubbles for $20 \mathrm{~min}$ or until no bubbles were observed. The relative difference in flowrate (percentage loss of hydraulic conductivity, PLC) before and after flushing was plotted against corresponding stem water potential to build stem vulnerability curves. PLC (\%) was calculated as:

$$
\mathrm{PLC}=100 \times\left(1-\frac{K_{\mathrm{i}}}{K_{\mathrm{m}}}\right)
$$

( $K_{i}$, initial conductivity; $K_{m}$, maximum conductivity after flushing).

For PLC measurements, pre-flush $K_{i}$ was compared with the post-flush $K_{m}$ of the same segment with all embolism removed [57]. A length of 5-8 cm was preferred as it was the maximum length of unbranched stem segment available which directly supported the canopy leaves in this study case. This length was less than the MVL of the two species and therefore open vessels were present in segments used for hydraulic measurements. A relatively low-pressure head of $0.003 \mathrm{MPa}$ was applied to avoid pushing gas bubbles from the open vessels present in the segments. The pressure was insufficient for removing emboli from open vessels in the studied species, based on the measurements of wood anatomy (narrow vessel) and stable flowrate (if not, the flowrate should increase during initial flow measurements). Therefore, the PLC could be considered as a proportion of the conductivity, and the influence of segment sample length could be slight, especially in the case where the bench dehydration method was utilized [58].

\subsection{Stem Hydraulic Conductivity and Huber Value}

The same protocol for sample collection was followed and the same individual plants were collected as described above. Two stems for each tree, and 5-6 trees for each species, were collected in the predawn. Stem segments 8-10 cm in length and 4-6 $\mathrm{mm}$ in diameter were obtained from those long branches. The hydraulic conductivity was measured by using fresh samples after flushing to minimize the potential possibility of native embolism, and also standardize the data. The cross-sectional area of xylem $\left(A_{S}\right)$ and the leaf area $\left(A_{L}\right)$ supported by each stem were measured and used to calculate sapwood-specific hydraulic conductivity $\left(K_{s}\right)$ and leaf-specific hydraulic conductivity $\left(K_{L}\right)$, respectively. The conductive section diameter was measured at the proximal end of the sample by using a digital caliper (K11100; Kincrome, Scoresby, VIC, Australia). Leaf area was determined using a leaf area meter (Li-3100C; Li-Cor, Lincoln, NE, USA). Huber value (HV) was the ratio of the sapwood cross-sectional area $\left(A_{S}\right)$ to the projected leaf area $\left(A_{L}\right)$.

The hydraulic conductivity measured using short segments was relatively higher because those segments contained open vessels, but was a compromise with measuring hydraulic conductivity in stems of similar branching order with similar stem size. The influence of side lateral branches was avoided, and the potential wounding effect caused by extended flushing time was also reduced $[59,60]$. Meanwhile, the measurements provided a good basis for comparison between sites in this study, and the overestimation of hydraulic conductivity should be paid attention when comparing values of $K_{S}$ and $K_{L}$ reported here with values determined using different protocols in other studies. 


\subsection{Wood Density and Sapwood Water Content}

Three segments were collected from each tree with similar diameters among those plant materials used for hydraulic measurements. The stem segments were trimmed to $2-3 \mathrm{~cm}$ sections and then the bark and the piths were removed. After rehydration overnight, fresh mass $\left(M_{\mathrm{f}}\right)$ was measured by using a digital balance (precision $0.0001 \mathrm{~g}$; ML204; Mettler-Toledo, Zurich, Switzerland) after surface water was wiped off. The volume of the sample was determined by using the water displacement method [61]. Dry mass $\left(M_{\mathrm{d}}\right)$ was measured after $104{ }^{\circ} \mathrm{C}$ oven-drying for $72 \mathrm{~h}$. Wood density (WD, g/ $\mathrm{cm}^{3}$ ) was calculated by the ratio of the dry mass to the volume. Sapwood water content was calculated by:

$$
\mathrm{SWC}=\frac{M_{\mathrm{f}}-M_{\mathrm{d}}}{M_{\mathrm{d}}}
$$

\subsection{Water Potential and Hydraulic Safety Margin}

Two mature leaves in each tree were sampled from 5 individuals in the dry season. For predawn water potential $\left(\Psi_{\mathrm{pd}}\right)$, the leaves were collected at 05:00-06:00, and immediately placed into humidified zip seal bags. Samples were put in a cooler box and transported to the laboratory within 30 min or measured on-site, using the Scholander-type pressure chamber.

For midday water potential measurements, samples were collected at 12:30-13:30. Particularly, aluminum foils and plastic bags were used to bag the leaves at predawn, thus the bagged leaf water potential represented the midday stem water potential ( $\left.\Psi_{\text {md-stem }}\right)$, while the unbagged leaves were measured as midday leaf water potential $\left(\Psi_{\text {md-leaf }}\right)$.

The water potential data were collected on a third sunny day with no observed rainfall in the previous two days. The $\Psi_{\text {md-stem }}$ was considered as minimum stem water potential $\left(\Psi_{\min }\right)$ in this study. Thus, two types of hydraulic safety margin (HSM) for stem xylem were calculated: $\mathrm{HSM}_{50}=\Psi_{\min }-\mathrm{P}_{50}$, and $\mathrm{HSM}_{88}=\Psi_{\min }-\mathrm{P}_{88}$, where $\mathrm{P}_{50}$ and $\mathrm{P}_{88}$ stand for stem water potential at $50 \%$ and $88 \%$ loss of conductivity, respectively [10,62].

\subsection{Wood Anatomy}

Branches used in hydraulic measurements were collected, and 10-20 $\mu \mathrm{m}$ thick crosssections were obtained with a microtome (SM2010R; Leica Biosystems, Nussloch, Germany) and stained using a safranin-methylene blue solution to distinguish lignified cells (in red) and parenchymal cells (in blue). Observations of stem sections were carried out using a light microscope (DM3000LED; Leica Microsystems, Wetzlar, Germany). The inspection of the stem xylem structure was undertaken and measured under objective lenses of $\times 10$ and $\times 40$ magnification. The microscopic images were captured by a digital camera (DFC295; Leica Microsystems, Wetzlar, Germany) attached to the light microscope. Stem images were analyzed and measured with Image software (National Institutes of Health, Bethesda, MD, USA, freely available from the website https://imagej.nih.gov/ij/). Arithmetic vessel diameter $(D)$ was defined as the equivalent circle diameter. The hydraulic weighted diameter $\left(D_{\mathrm{H}}\right)$ was calculated as:

$$
D_{H}=\left(\frac{\sum D^{4}}{N}\right)^{\frac{1}{4}}
$$

where $D$ is the diameter of each vessel and $N$ is the number of total vessels [63]. Vessel density (VD) was the average number of vessels per unit area for each section. Vessel wall reinforcement (VWR) was determined as:

$$
\mathrm{VWR}=\left(\frac{2 T_{\mathrm{W}}}{D}\right)^{2}
$$


where $T_{\mathrm{w}}$ is the thickness of the vessel wall [64]. All parameters were averaged for at least 50 vessels for each stem section, based on two stem sections per tree and five trees per species in each site.

\subsection{Statistics Analysis}

All statistical analyses in this study were performed with R (version 3.5.1, R Core Team, Vienna, Austria, https://www.R-project.org/). Stem vulnerability curves were fitted using the Weibull model and key traits (i.e., $\mathrm{P}_{12}, \mathrm{P}_{50}, \mathrm{P}_{88}$ ) were statistically tested by comparing bootstrap confidence intervals using the fitplc script [65]. Significant differences in key traits obtained from vulnerability curves across field sites were achieved when their 95\% confidence intervals did not overlap. For other traits, statistical differences across sampling sites were tested using one-way ANOVA, and means of each trait were compared using Tukey's HSD (Honestly Significant Difference) test with an alpha of 5\%. Correlations among hydraulic traits were examined using Pearson's correlation coefficient. Data were log-transformed if necessary to meet the assumption of homoscedasticity.

\section{Results}

\subsection{Changes in Xylem Hydraulic Traits along the Latitudinal Gradient}

Based on the meteorological information, from high latitude to low latitude, mean annual temperature (MAT), mean annual precipitation (MAP), mean annual potential evapotranspiration (PET), and precipitation seasonality $\left(\mathrm{P}_{\mathrm{S}}\right)$ increased, but minimum monthly precipitation of the year $\left(\mathrm{P}_{\min }\right)$ and aridity index $(\mathrm{AI})$ decreased (Table 1$)$.

Water potentials at $50 \%$ loss of xylem conductivity $\left(\mathrm{P}_{50}\right)$ of both species became more negative (more resistant to embolism) from higher to lower latitudes (Figure 1). For both species, lower xylem water potentials (more negative) occurred at the higher latitude site (Marlow) with lower MAT and MAP (Tables 1 and 2). The hydraulic safety tended to increase with increasing MAT along the latitudinal gradient. Thus, embolism resistance (as indicated by $\left.\mathrm{P}_{50}\right)$ and hydraulic safety margin $\left(\mathrm{HSM}_{50}\right)$ increased with increasing MAT (Figure 2a,b). Among the three sites, the greatest embolism resistance, widest $\mathrm{HSM}_{50}$, and highest vessel wall reinforcement (VWR) were found in the lowest latitude site (DRO) in both species (Tables 2 and 3).
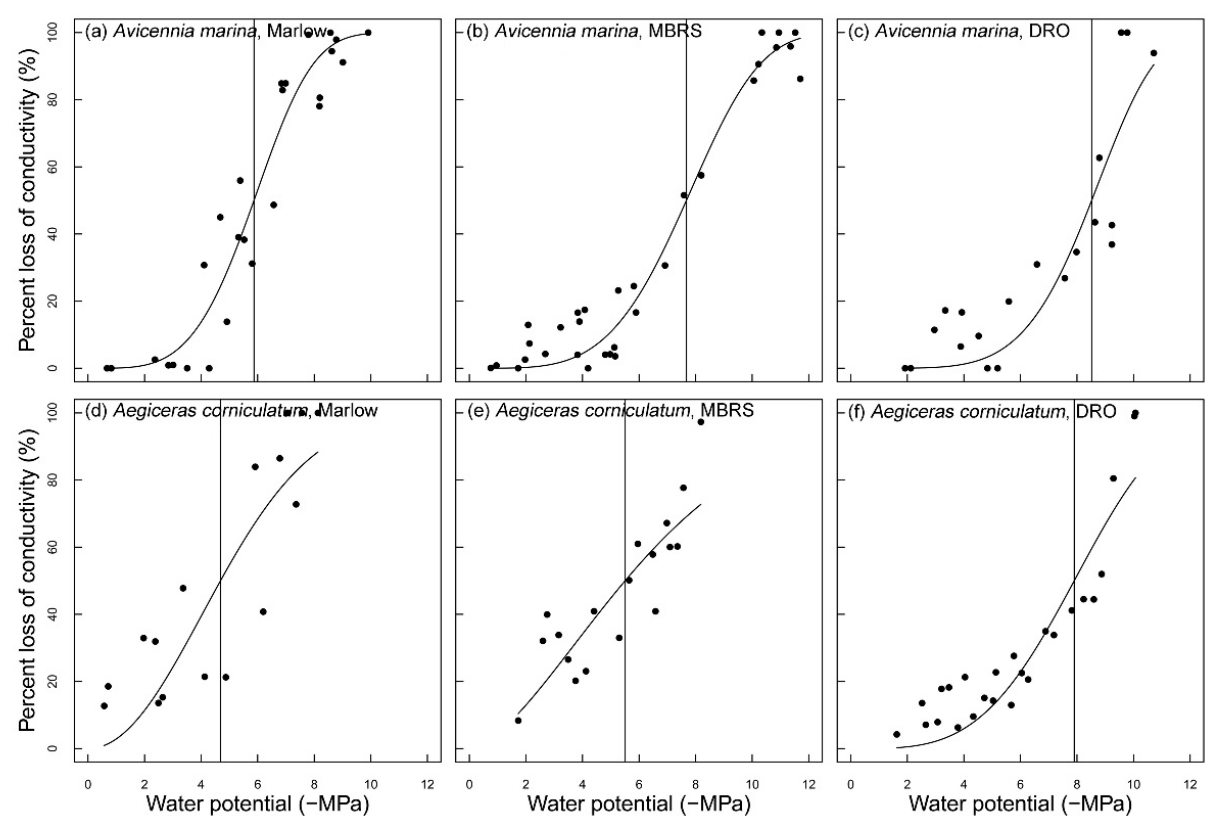

Figure 1. Percentage loss of xylem conductivity to water potential of two mangrove species. Black vertical lines indicate xylem water potential inducing $50 \%$ loss of conductivity $\left(\mathrm{P}_{50}\right)$. Stem vulnerability curve of Avicennia marina across three sites $(\mathbf{a}-\mathbf{c})$ and the vulnerability curve of Aegiceras corniculatum across three sites $(\mathbf{d}-\mathbf{f})$. 
Table 2. Xylem embolism resistance $\left(\mathrm{P}_{12}, \mathrm{P}_{50}, \mathrm{P}_{88} ;-\mathrm{MPa}\right)$; hydraulic safety margin $\left(\mathrm{HSM}_{50}, \mathrm{HSM}_{88} ; \mathrm{MPa}\right) ; \Psi_{\mathrm{pd}}, \mathrm{predawn}$ water potential (-MPa); $\Psi_{\text {md-leaf }}$, midday leaf water potential $(-\mathrm{MPa}) ; \Psi_{\text {md-stem }}$, midday stem water potential ( $\left.-\mathrm{MPa}\right)$ of the two mangrove species in the three sample sites. Water potential values are shown as mean \pm standard error $(\mathrm{SE}, \mathrm{n}=5)$.

\begin{tabular}{|c|c|c|c|c|c|c|c|c|c|}
\hline Species & Site & $\mathbf{P}_{12}$ & $P_{50}$ & $\mathrm{P}_{88}$ & $\mathrm{HSM}_{50}$ & $\mathrm{HSM}_{88}$ & $\Psi_{p d}$ & $\Psi_{\text {md-leaf }}$ & $\Psi_{\text {md-stem }}$ \\
\hline \multirow{3}{*}{ Avicennia marina } & Marlow & $3.86[3.29,4.56]$ & $5.87[5.46,6.24]$ & $7.75[7.11,8.37]$ & 1.45 & 3.33 & $3.14 \pm 0.05 \mathrm{a}$ & $5.32 \pm 0.13 a$ & $4.42 \pm 0.04 a$ \\
\hline & MBRS & $5.13[4.59,5.53]$ & $7.67[7.39,7.88]$ & $10.02[9.57,10.56]$ & 3.25 & 5.6 & $2.20 \pm 0.22 \mathrm{~b}$ & $5.19 \pm 0.05 a$ & $4.42 \pm 0.28 \mathrm{a}$ \\
\hline & DRO & $6.20[4.64,8.15]$ & $8.52[7.98,9.40]$ & $10.51[9.41,14.55]$ & 4.93 & 6.92 & $3.24 \pm 0.15 a$ & $4.72 \pm 0.15 \mathrm{~b}$ & $3.59 \pm 0.11 \mathrm{~b}$ \\
\hline \multirow{3}{*}{ Aegiceras corniculatum } & Marlow & $2.06[0.90,4.59]$ & $4.68[3.57,6.01]$ & $8.08[6.54,13.15]$ & 1.08 & 4.48 & $2.90 \pm 0.12 \mathrm{a}$ & $4.40 \pm 0.13 a$ & $3.60 \pm 0.05 a$ \\
\hline & MBRS & $1.90[1.04,2.92]$ & $5.51[4.97,6.31]$ & $11.13[8.82,20.05]$ & 3.05 & 8.67 & $1.97 \pm 0.06 b$ & $3.25 \pm 0.07 \mathrm{c}$ & $2.46 \pm 0.09 b$ \\
\hline & DRO & $4.92[3.71,5.64]$ & $7.90[7.51,9.34]$ & $10.81[9.87,17.01]$ & 5.18 & 8.09 & $2.14 \pm 0.05 \mathrm{~b}$ & $3.79 \pm 0.06 \mathrm{~b}$ & $2.72 \pm 0.05 \mathrm{~b}$ \\
\hline
\end{tabular}

Note. Numbers in brackets are lower and upper bound of $95 \%$ confidence interval. Trait values followed by the same letter (e.g., a \& ab) do not differ significantly $(p>0.05)$.
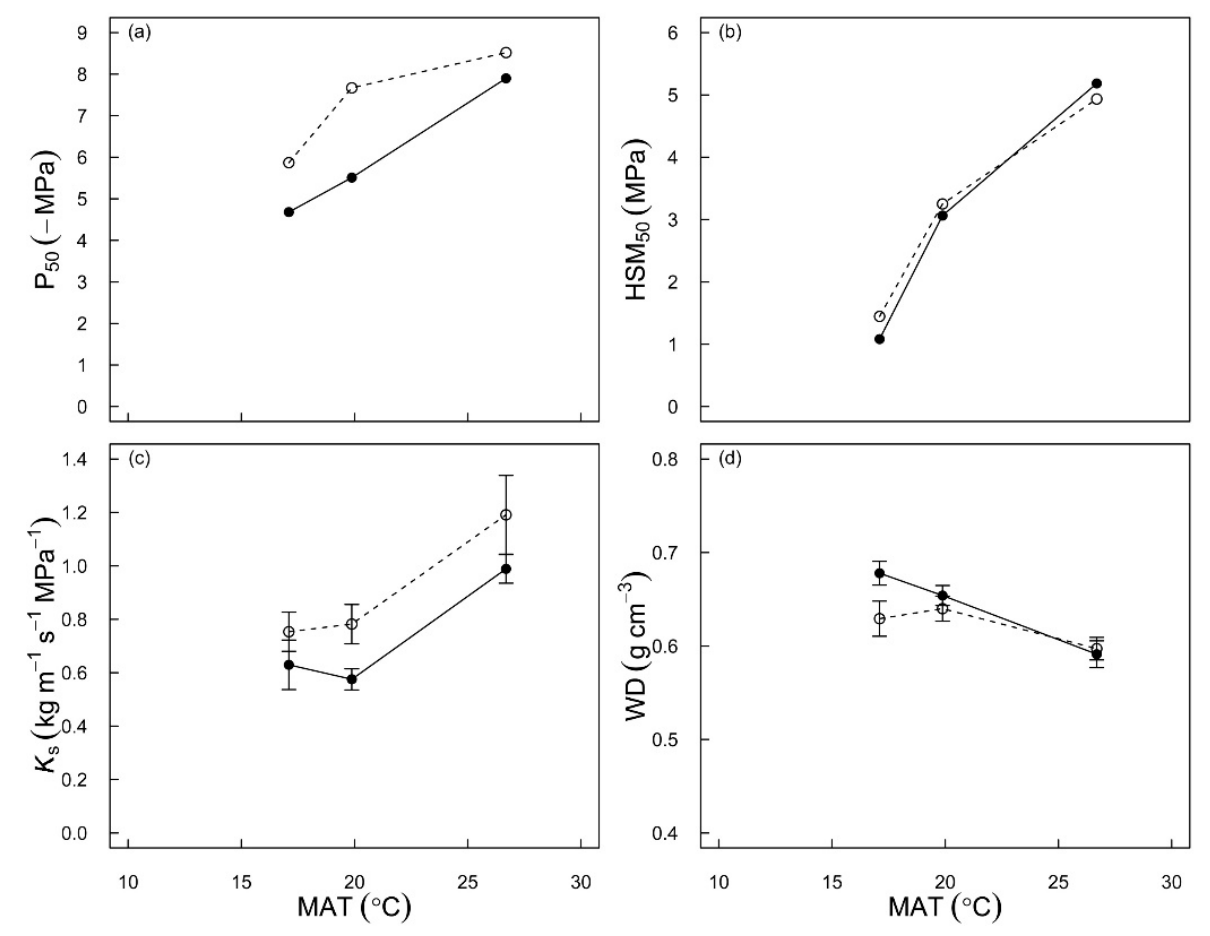

Figure 2. The variations of hydraulic traits ((a) water potential at $50 \%$ loss of conductivity, $\mathrm{P}_{50}$; (b) hydraulic safety margin, $\mathrm{HSM}_{50}$; (c) sapwood-specific hydraulic conductivity, $K_{\mathrm{S}}$; (d) wood density, WD) across two mangrove species in three sampling sites with different mean annual temperature $\left(\mathrm{MAT} ;{ }^{\circ} \mathrm{C}\right)$. Open circles represent Avicennia marina and filled circles represent Aegiceras corniculatum. Error bars indicate standard error of mean.

Table 3. Values of key hydraulic traits of two mangrove species across three sample sites. Hydraulic traits are shown as mean \pm standard error (SE, $\mathrm{n}=5$ except MVL, which is $\mathrm{n}=3)$. $K_{\mathrm{L}}$ : leaf specific hydraulic conductivity $\left(\mathrm{kg} \mathrm{m}^{-1} \mathrm{~s}^{-1} \mathrm{MPa}^{-1}\right)$. $K_{\mathrm{S}}$ : sapwood-specific hydraulic conductivity $\left(\mathrm{kg} \mathrm{m}^{-1} \mathrm{~s}^{-1} \mathrm{MPa}^{-1}\right)$. MVL: maximum vessel length (cm). SWC: sapwood water content $(\mathrm{g} / \mathrm{g})$. $D_{\mathrm{H}}$ : hydraulic weighted diameter $(\mu \mathrm{m})$. VD: vessel density $\left(\right.$ no. $\left.\mathrm{mm}^{-2}\right)$. WD: wood density $\left(\mathrm{g} / \mathrm{cm}^{3}\right)$. VWR: vessel wall reinforcement $(\mu \mathrm{m} / \mu \mathrm{m})^{2}$. HV: Huber value $\left(\mathrm{m}^{2} / \mathrm{m}^{2}\right)$.

\begin{tabular}{|c|c|c|c|c|c|c|c|c|c|c|}
\hline Species & Site & $K_{L} \times 10^{4}$ & $K_{\mathrm{S}}$ & MVL & SWC & $D_{\mathbf{H}}$ & VD & WD & VWR & HVx10 \\
\hline \multirow{3}{*}{ Avicennia marina } & Marlow & $2.83 \pm 0.51 \mathrm{a}$ & $0.75 \pm 0.07 \mathrm{~b}$ & $23.00 \pm 6.55 \mathrm{a}$ & $0.96 \pm 0.05 \mathrm{a}$ & $40.41 \pm 1.97 \mathrm{a}$ & $74.83 \pm 8.82 \mathrm{a}$ & $0.63 \pm 0.02 \mathrm{a}$ & $0.059 \pm 0.0014 \mathrm{~b}$ & $4.40 \pm 0.59 \mathrm{a}$ \\
\hline & MBRS & $2.56 \pm 0.24 a$ & $0.78 \pm 0.07 \mathrm{ab}$ & $27.27 \pm 4.57 \mathrm{a}$ & $0.95 \pm 0.04 a$ & $37.11 \pm 1.22 \mathrm{a}$ & $85.08 \pm 4.62 \mathrm{a}$ & $0.64 \pm 0.01 \mathrm{a}$ & $0.067 \pm 0.0061 \mathrm{~b}$ & $4.08 \pm 0.63 a$ \\
\hline & DRO & $3.84 \pm 0.52 a$ & $1.19 \pm 0.15 a$ & $30.00 \pm 2.10 \mathrm{a}$ & $1.01 \pm 0.03 \mathrm{a}$ & $35.20 \pm 1.00 \mathrm{a}$ & $86.53 \pm 6.82 a$ & $0.60 \pm 0.01 \mathrm{a}$ & $0.098 \pm 0.0071 \mathrm{a}$ & $3.33 \pm 0.41 \mathrm{a}$ \\
\hline \multirow{3}{*}{ Aegiceras corniculatum } & Marlow & $1.68 \pm 0.20 \mathrm{~b}$ & $0.63 \pm 0.09 \mathrm{~b}$ & $22.53 \pm 1.37 \mathrm{a}$ & $0.78 \pm 0.02 \mathrm{a}$ & $21.78 \pm 0.81 \mathrm{a}$ & $310.54 \pm 8.02 \mathrm{~b}$ & $0.68 \pm 0.01 \mathrm{a}$ & $0.037 \pm 0.0021 \mathrm{~b}$ & $2.79 \pm 0.35 \mathrm{~b}$ \\
\hline & MBRS & $1.66 \pm 0.37 \mathrm{~b}$ & $0.58 \pm 0.04 \mathrm{~b}$ & $25.93 \pm 4.63 \mathrm{a}$ & $0.82 \pm 0.02 \mathrm{a}$ & $20.75 \pm 0.40 \mathrm{a}$ & $318.12 \pm 19.30 \mathrm{~b}$ & $0.65 \pm 0.01 \mathrm{a}$ & $0.035 \pm 0.0010 \mathrm{~b}$ & $2.72 \pm 0.28 \mathrm{~b}$ \\
\hline & DRO & $4.02 \pm 0.73 a$ & $0.99 \pm 0.05 \mathrm{a}$ & $27.77 \pm 4.77 \mathrm{a}$ & $0.86 \pm 0.04 a$ & $21.80 \pm 0.41 \mathrm{a}$ & $402.90 \pm 22.08 a$ & $0.59 \pm 0.01 \mathrm{~b}$ & $0.047 \pm 0.0027 \mathrm{a}$ & $4.64 \pm 0.44 a$ \\
\hline
\end{tabular}

Note. Trait values followed by the same letter (e.g., a \& ab) do not differ significantly $(p>0.05)$.

Other xylem hydraulic traits also showed variation across the latitudinal gradient. The highest sapwood-specific hydraulic conductivities $\left(K_{S}\right)$ were found in the lowest latitude site with the highest MAT for both species (Table 3, Figure 2c). In contrast, wood density (WD) in both species tended to decrease with increasing MAT (Figure 2d). 


\subsection{Difference in Hydraulic Traits and Plasticity between Two Species}

Different plasticity of xylem hydraulic traits with latitudinal change between the two species was found. In Avicennia, hydraulic traits including leaf-specific hydraulic conductivity $\left(K_{\mathrm{L}}\right)$, vessel density (VD), wood density (WD), and Huber value (HV) were similar among the three sites. However, for Aegiceras, these hydraulic traits of the lowest latitude site, DRO, were significantly different from the other two sites. Its $K_{\mathrm{L}}, \mathrm{VD}$, and $\mathrm{HV}$ were the highest while the WD was the lowest at DRO. In addition, there was no significant difference in maximum vessel length (MVL), sapwood water content (SWC), and hydraulic weighted diameter $\left(D_{\mathrm{H}}\right)$ across latitude gradients in both species (Table 3). Avicennia had a larger vessel diameter compared with Aegiceras in all sites, while Aegiceras had greater vessel density. Both species exhibited high embolism resistance, with Avicennia having consistently more negative $\mathrm{P}_{12}$ and $\mathrm{P}_{50}$ than Aegiceras, while values of $\mathrm{P}_{88}$ were similar for the two species at each site (Table 2).

\subsection{Correlations between Hydraulic Traits}

Notably, $K_{\mathrm{S}}$ was positively correlated with embolism resistance, as indicated by $\mathrm{P}_{50}$ (Figure 3; $R^{2}=0.72, p<0.05$ ). Significant negative relationships were found between WD and embolism resistance (Figure $4 c ; R^{2}=0.68, p<0.05$ ), as well as between WD and $K_{\mathrm{S}}$ (Figure $4 \mathrm{a} ; R^{2}=0.73, p<0.05$ ). VWR and embolism resistance displayed a marginally significant and positive relationship (Figure $4 \mathrm{~d} ; R^{2}=0.47, p=0.0801$ ), while $K_{\mathrm{S}}$ was positively correlated with VWR (Figure $4 \mathrm{~b} ; R^{2}=0.68, p<0.05$ ).

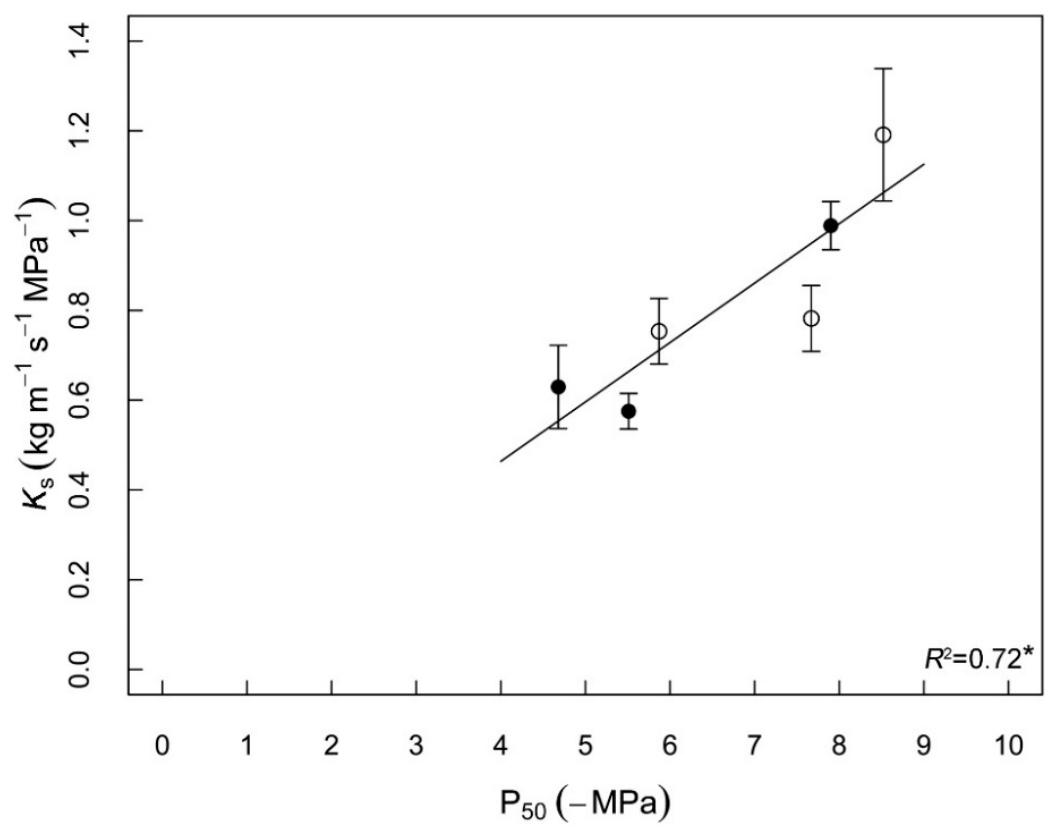

Figure 3. The relationship between water potential at $50 \%$ loss of conductivity $\left(\mathrm{P}_{50}\right)$ and sapwoodspecific hydraulic conductivity $\left(K_{\mathrm{S}}\right)$ across the two mangrove species in the three sites. Open circles represent Avicennia marina and filled circles represent Aegiceras corniculatum. Error bars indicate standard error of mean. Adjusted $R^{2}$ of significant Pearson's correlation is shown. Asterisk indicates significance). Asterisk indicates significance level $\left({ }^{*} p<0.05\right)$. 


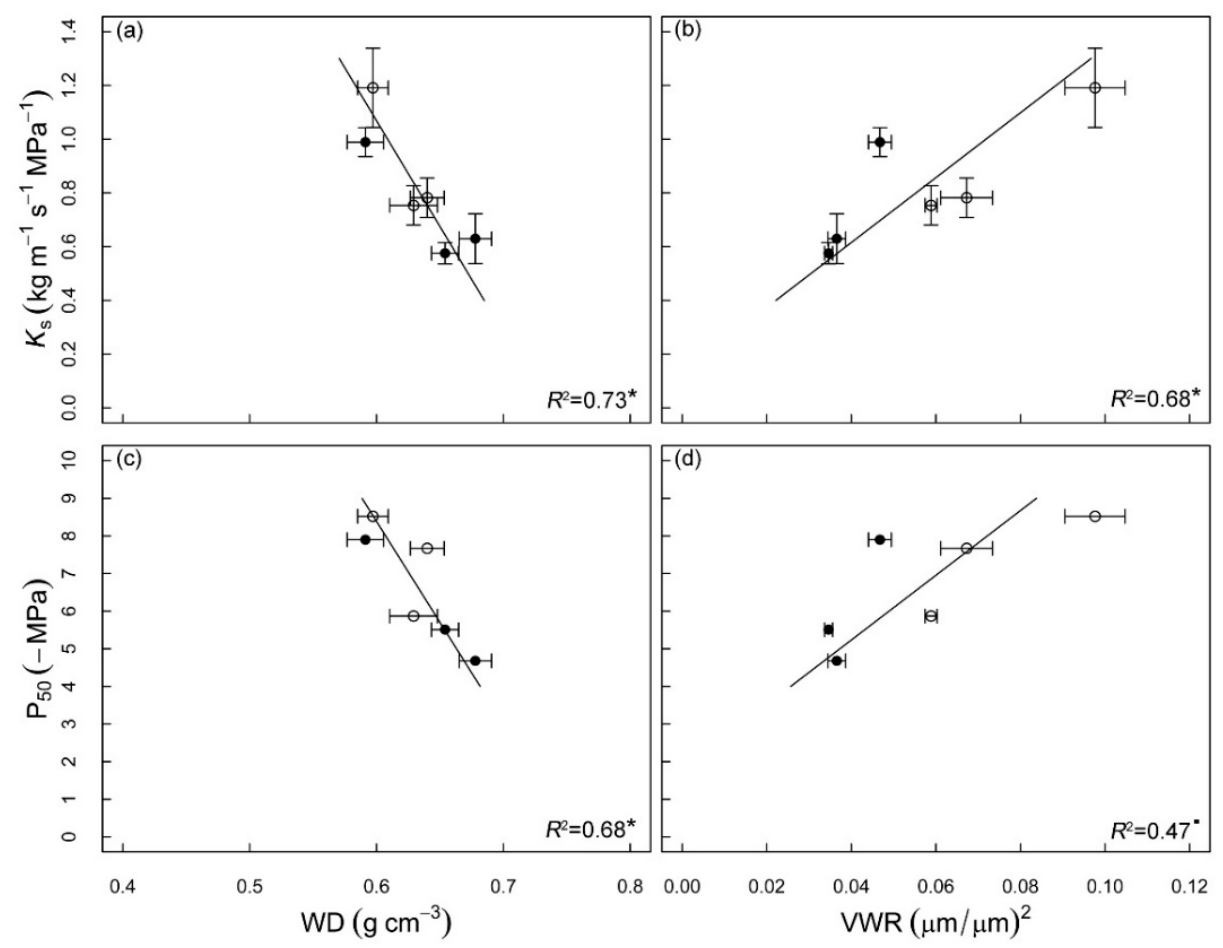

Figure 4. The relationship between wood density (WD) and sapwood-specific hydraulic conductivity $\left(K_{S} ; \mathbf{a}\right)$, water potential at $50 \%$ loss of conductivity $\left(\mathrm{P}_{50} ; \mathrm{c}\right)$, as well as the relationship between vessel wall reinforcement (VWR) and sapwood-specific hydraulic conductivity $\left(K_{S} ; \mathbf{b}\right)$, water potential at $50 \%$ loss of conductivity $\left(\mathrm{P}_{50} ; \mathrm{d}\right)$ across the two mangrove species in the three sites. Open circles represent Avicennia marina and filled circles represent Aegiceras corniculatum. Error bars indicate standard error of mean. Adjusted $R^{2}$ of significant Pearson's correlation is shown. Asterisk indicates significance marginally significant). Asterisk indicates significance level $\left({ }^{*} p<0.05\right.$; --marginally significant).

\section{Discussion}

Our study revealed a high level of variation in traits related to water transport and hydraulic safety in two mangrove species growing across a latitudinal gradient. Higher hydraulic conductivity and resistance to cavitation were found at lower latitude sites with warmer and wetter climates. Thus, the latitudinal variation in mangrove hydraulics cannot be explained by differences in mean annual precipitation (MAP), but could be related to evaporative demand and rainfall seasonality. Higher temperatures and vapor pressure deficits (VPDs) can induce higher rates of transpiration and greater tensions within the xylem. For plants growing in high-salinity environments, this may require higher embolism resistance to ensure plant growth and survival. In addition, a tradeoff between hydraulic efficiency and safety was not found in mangroves studied here.

\subsection{Variation in Hydraulic Traits along the Latitudinal Gradient}

Resistance to embolism varied in both mangrove species along the latitudinal gradient, with the highest resistance found at the lowest latitude site. This cannot be explained by MAP as the lower latitude sites have higher precipitation, but could be related to the differences in temperature and rainfall seasonality. Mean annual temperature (MAT) increases from the high to low latitude, and higher temperatures, usually lead to a greater VPD and transpiration rates, which potentially create higher tensions (more negative water potential) within the xylem. Thus, plants at the lower latitude may be at higher risk of xylem embolism during periods of low precipitation [66]. In this case, the two mangrove species may require greater resistance to xylem dysfunction (more negative $P_{50}$ and wider HSM) to maintain hydraulic function at the lower latitude sites. Additionally, 
both species exhibited the highest $K_{\mathrm{S}}$ at the lowest latitude site (DRO), which would assist in maintaining higher transpiration rates while minimizing the root to leaf water potential gradient [67]. Although aridity index (AI) decreased with declining latitude and DRO was the wettest site based on MAP and AI, the rainfall is more seasonally variable (indicated by $\left.\mathrm{P}_{\mathrm{S}}\right)$ at lower latitude sites. Indeed, the minimum monthly precipitation of the year $\left(\mathrm{P}_{\min }\right)$ was the lowest at the lowest latitude site, DRO. The combination of higher temperatures and VPD during the driest months may expose mangroves at the lowest latitude site to greater risk of drought stress.

The difference in resistance to embolism and $K_{S}$ along the latitudinal gradient could be explained by vessel wall reinforcement (VWR) and wood density (WD). Across species and sites, VWR was positively related to embolism resistance $\left(P_{50}\right)$ (Figure $\left.4 \mathrm{~d}\right)$. This is consistent with previous studies showing a correlation between $\mathrm{P}_{50}$ and double wall thickness of xylem vessels [68]. It also suggests that intervessel pit membranes are thicker and less porous in populations with greater embolism resistance. Vessels conducting water at low water potentials (high tensions) also require greater structural reinforcement of the vessel walls to avoid implosion [69]. When embolism occurs, a large bending stress can increase on the wall between sap- and gas-filled vessels, and a higher VWR can help protect vessels during periods of extreme water deficit $[69,70]$. Less dense wood (i.e., more porous) was associated with higher hydraulic conductivity, indicated by a negative relationship (Figure 4a). Wood density is generally related to xylem volume allocation, and associated with not only the vessels, but also the fibers and parenchyma cells [70]. In accordance with hydraulic efficiency, vessel lumen diameter and vessel density combined to influence the hydraulic performance. Lighter wood with a more porous vessel structure is related to higher sapwood-specific conductivity [71,72]. Additionally, higher vessel density at the lower latitude sites can increase redundancy in the xylem by providing multiple routes for water flow when some vessels become embolized, thus it might lower the risk of hydraulic dysfunction [73].

Notably, instead of the expected hydraulic safety-efficiency tradeoff, a positive correlation between hydraulic safety and efficiency was observed (Figure 3), across two mangrove species and three sites. This result is consistent with the study of Liu et al. [74] showing that plant species with co-optimized hydraulic safety and efficiency may be favored by climatic filters such as strong seasonality (high $\mathrm{P}_{\mathrm{S}}$ ) and low $\mathrm{P}_{\min }$. On the other hand, compared with diverse plant species from a perspective of global interspecific analysis, the mangroves examined in this study show low hydraulic efficiency and high hydraulic safety, which could fit into the efficiency-safety tradeoff across the global scale [19,75].

\subsection{Different Hydraulic Plasticity between Two Species}

Mangrove plants are innately plastic for better adaptation to various environmental stresses (i.e., high temperatures, high transpiration demand, salinity, freshwater shortage). Here, both mangrove species studied showed high variation in embolism resistance $\left(\mathrm{P}_{50}\right)$, sapwood-specific hydraulic conductivity $\left(K_{S}\right)$, and vessel wall reinforcement (VWR). High plasticity in these hydraulic traits may be a fundamental factor that affords mangrove plants greater potential for acclimation and adaptation to changes in temperature, rainfall variation, aridity, and salinity. It has been found that mangrove plants have higher plasticity compared to other terrestrial species $[7,76,77]$. This high plasticity can assist mangrove plants in adapting to environmental variations associated with global climate change scenarios. An intraspecific plasticity in xylem hydraulic traits should be assessed across species distributions to determine its potential adaptability.

These two mangrove species showed different plasticity in some basic xylem structural traits. Aegiceras showed relatively greater plasticity in vessel density (VD), wood density (WD), and Huber value (HV) compared with Avicennia. The intraspecific plasticity in xylem structure relating to survival under harsh environmental conditions is beneficial; altering the embolism resistance would contribute to the differences in mangrove drought/salt tolerance over time and space [78]. Therefore, high plasticity in these structural traits 
in Aegiceras could at least partially explain its high variation in hydraulic performance (efficiency and safety). The higher plasticity of Aegiceras vessel structure may enable it to adapt to a wide range of environmental gradients. In contrast, Avicennia showed relatively stable vessel structure and thus a low plasticity in hydraulic traits such as vessel size and density. Avicennia, as one of the most common mangrove species with the widest distribution range [4], may use other mechanisms to adapt to environmental changes. With its high salt tolerance [5], this species may use special structural traits like internal secondary phloem strands in the xylem, with this adaptive trait linked to dry or saline environments in most cases $[79,80]$. The successive cambia in the wood anatomy of Avicennia also distinguish it from other mangrove species, with phloem and parenchyma formed in concentric bands that are close to the xylem tissue [81,82]. Moreover, with increasing salinity, the fraction of parenchyma tissues and fibers increases in the Avicennia genus $[79,83]$. These unique structures may potentially contribute to their adaptation to changes in salinity and aridity stress. Increased storage of water and carbohydrate in parenchyma cells directly adjacent to the xylem may assist in maintaining xylem water status and hydraulic function $[2,81]$. Avicennia likely depends on these special structural features rather than vessel size and density to adapt to changes in environmental conditions.

In these two species, Aegiceras has a safer hydraulic system compared with Avicennia. Small vessel diameter in Aegiceras could be important for lowering their vulnerability to embolism, owing to a lower probability of "rare pits" with a low resistance to air seeding [84]. The highest VD and most negative $P_{50}$ of the species were observed in the lowest latitude site, DRO. High vessel density would increase hydraulic efficiency, and also secure the hydraulic system by keeping a greater proportion of vessels filled with water when embolism occurs [78].

There was no significant difference in vessel diameter across three sites for both species ( $D$ and $D_{\mathrm{H}}, D$ has a similar variation trend to $D_{\mathrm{H}}$ in this study case), which is consistent with the observation of seven Eucalyptus species from dry and wet sites in Australia [29]. The structure of the xylem vessel is related to a physiological function, especially hydraulic transport and cavitation resistance [3]. The plasticity in vessel size is the anatomical adaptation which may confer higher safety to the vessel network under low xylem water potentials [12]. Although there was no significant difference at the vessel lumen level in our study, there may be greater variations at the pit level. Intervessel pit characteristics may be able to explain the differences in embolism resistance based on the air seeding hypothesis $[85,86]$.

\subsection{Implications for Mangrove Response to Climate Change}

A high plasticity in xylem resistance $\left(\mathrm{P}_{50}\right)$ to drought-induced embolism and a wide hydraulic safety margin suggest that mangroves may be able to cope with enhanced evaporative demand caused by warming. By 2050, the annual mean temperature is anticipated to increase by $1.2-2.2{ }^{\circ} \mathrm{C}$ in Australia [87]. High variations in water transport and hydraulic safety in mangroves along the latitudinal gradients revealed in this study suggest that warming could impact their physiology and water use. $K_{\mathrm{S}}$ increased with increasing temperature and decreasing latitude in both species. Higher water transport efficiency might support higher photosynthetic carbon assimilation, which is vital for survival and growth in a warmer climate [88]. Therefore, rising temperature could positively influence physiological performance and may help expand the range of these mangrove plants and, actually, the poleward expansion of mangrove forests has been observed in Australia (1.7 latitude degrees per decade) [89]. They are currently floristically diverse in tropical regions compared to subtropical areas, and do not expand to temperate/cold climate zones $[1,15]$. This pattern may change under climate warming. Additionally, the differential responses to the environmental variation found between the two species suggests changes in the species composition of mangrove forests [89,90]. Notably, some climate extremes such as heatwaves may push mangroves to the brink of hydraulic failure. Catastrophic dieback 
of mangroves in recent years has been reported, and is thought to be related to extreme weather events $[40,42]$.

Rainfall plays a crucial role in the water balance of mangroves, and changes in rainfall patterns associated with global climate change could also influence mangrove physiological performance. Mangrove plants are successful in tropical areas with high MAT and MAP, but the most negative $P_{50}$ was found at the lowest latitude site (DRO). This suggests that the $P_{\min }$ and $P_{S}$ could impact the embolism resistance for these two species. Low $P_{\min }$ and high $\mathrm{P}_{\mathrm{S}}$ could lead to a short-term water stress for mangrove plants, especially for the low-latitude site with higher temperatures. The high seasonality of rainfall coupled with the impact of high MAT could result in an occasional drought even in the humid region. Changes in precipitation regimes could be a considerable climatic element that impacts the mangroves. Evident decreasing rainfall and prolonged drought in coastal areas, including Australia, have been documented [91-94]. A reduction of 2-5\% in annual rainfall is predicted by 2030 in Australia except for the far north regions. Seasonal variation is also predicted to increase, with a 5-10\% decline in rainfall during the winter and spring [87]. Low rainfall can lead to the accumulation of ocean-sourced salts and increase the salinity of soil pore water. In additional to providing freshwater input and lowering soil salinity, rainfall can also decrease soil temperature, improving relative humidity and reducing air temperature in mangrove areas $[80,95]$. Under the development of the hypersaline condition, mangroves face the intense challenge of physiological stress, especially when this is combined with periods of high aridity. High salinity in combination with high VPD and dehydration due to both warming and decreasing rainfall can therefore threaten the survival and growth of mangroves $[3,42,93]$.

\section{Conclusions}

Our study demonstrated a series of variations in the xylem structure and function of two mangrove species spanning a latitudinal gradient from $16^{\circ} \mathrm{S}$ to $33^{\circ} \mathrm{S}$ along the east coast of Australia. The highest resistance to embolism was observed in the lowest latitude site. This pattern may be explained by the highest average temperatures, evaporative demands, and lowest $P_{\min }$. Between the two studied species, Aegiceras corniculatum has greater plasticity in xylem structural traits (vessel density and wood density) allowing greater potential for adaptation to various environmental conditions. Avicennia marina showed low plasticity in xylem structural traits, however, the successive cambia and internal phloem present in this species may allow it to adapt to a wider range of environmental conditions. There was no difference in vessel diameter across latitude gradients in each species, suggesting vessel size is a relatively stable trait. We also observed a positive correlation between safety and efficiency, suggesting the absence of the hydraulic efficiency-safety tradeoff in the present case. Mangroves with relatively low hydraulic efficiency and high safety compared to other lineages may represent an extreme condition within the global database. Additionally, while climate warming may help expand the distribution of mangroves, the predicted decrease in rainfall and increasing temperature, as well as rainfall fluctuations, could increase the risk of hydraulic failure and mortality of mangroves.

Author Contributions: Conceptualization, X.J., B.C. and K.-F.C.; methodology, X.J. and B.C.; software, X.J. and W.S.; validation, X.J.; formal analysis, X.J. and W.S.; investigation, X.J. and X.-Y.G.; resources, B.C.; data curation, X.J.; writing-original draft preparation, X.J.; writing-review and editing, X.J., B.C., Y.-J.Z., X.-Y.G., W.S. and K.-F.C.; visualization, X.J. and W.S.; supervision, B.C. and K.-F.C.; project administration, B.C. and K.-F.C.; funding acquisition, B.C. and K.-F.C. All authors have read and agreed to the published version of the manuscript.

Funding: This research was funded by the National Natural Science Foundation of China (31670406), Bagui Scholarship of Guangxi Zhuang Autonomous Region (C33600992001), Future Fellowship of Australian Research Council (FT130101115), Australia \& Pacific Science Foundation (APSF1703), China Scholarship Council (201606660005).

Institutional Review Board Statement: Not applicable. 
Informed Consent Statement: Not applicable.

Data Availability Statement: Please refer to Section 2.1 in this article for the sources of the publicly archived data used in this study.

Acknowledgments: We thank the Moreton Bay Research Station (University of Queensland, especially the field assistance provided by Martin Wynne), and the Daintree Rainforest Observatory (James Cook University) for professional research facility access and fieldwork lab space with accommodation. Jennifer Peters and Jinyan Yang are thanked for field assistance. We also appreciate the kindly and valuable suggestions from Catherine Lovelock and Norman Duke.

Conflicts of Interest: The authors declare no conflict of interest.

\section{References}

1. Duke, N.C.; Ball, M.C.; Ellison, J.C. Factors influencing biodiversity and distributional gradients in mangroves. Glob. Ecol. Biogeogr. Lett. 1998, 7, 27. [CrossRef]

2. Nguyen, H.T.; Stanton, D.E.; Schmitz, N.; Farquhar, G.D.; Ball, M.C. Growth responses of the mangrove Avicennia marina to salinity: Development and function of shoot hydraulic systems require saline conditions. Ann. Bot. 2015, 115, 397-407. [CrossRef] [PubMed]

3. Reef, R.; Lovelock, C.E. Regulation of water balance in mangroves. Ann. Bot. 2015, 115, 385-395. [CrossRef]

4. Quisthoudt, K.; Schmitz, N.; Randin, C.F.; Dahdouh-Guebas, F.; Robert, E.M.R.; Koedam, N. Temperature variation among man-grove latitudinal range limits worldwide. Trees 2012, 26, 1919-1931. [CrossRef]

5. Nguyen, H.T.; Meir, P.; Sack, L.; Evans, J.R.; Oliveira, R.S.; Ball, M.C. Leaf water storage increases with salinity and aridity in the mangrove Avicennia marina: Integration of leaf structure, osmotic adjustment and access to multiple water sources. Plant Cell Environ. 2017, 40, 1576-1591. [CrossRef] [PubMed]

6. Barraclough, A.D.; Cusens, J.; Zweifel, R.; Leuzinger, S. Environmental drivers of stem radius change and heterogeneity of stem radial water storage in the mangrove Avicennia marina (Forssk.) Vierh. Agric. For. Meteorol. 2020, 280, 107764. [CrossRef]

7. Fazlioglu, F.; Chen, L. Introduced non-native mangroves express better growth performance than co-occurring native man-groves. Sci. Rep. 2020, 10, 1-11. [CrossRef]

8. Sobrado, M.A. Relation of water transport to leaf gas exchange properties in three mangrove species. Trees 2000, 14, $258-262$. [CrossRef]

9. Lovelock, C.E.; Feller, I.C.; Ball, M.C.; Bettina, M.J.E.; Ewe, M.L. Differences in plant function in phosphorus- and nitro-gen-limited mangrove ecosystems. New Phytol. 2006, 172, 514-522. [CrossRef]

10. Choat, B.; Jansen, S.; Brodribb, T.J.; Cochard, H.; Delzon, S.; Bhaskar, R.; Bucci, S.J.; Feild, T.S.; Gleason, S.M.; Hacke, U.G.; et al. Global convergence in the vulnerability of forests to drought. Nature 2012, 491, 752-755. [CrossRef] [PubMed]

11. Tyree, M.T.; Davis, S.D.; Cochard, H. Biophysical perspectives of xylem evolution: Is there a tradeoff of hydraulic efficiency for vulnerability to dysfunction? IAWA J. 1994, 15, 335-360. [CrossRef]

12. Melcher, P.J.; Goldstein, G.; Meinzer, F.C.; Yount, D.E.; Jones, T.J.; Holbrook, N.M.; Huang, C.X. Water relations of coastal and estuarine Rhizophora mangle: Xylem pressure potential and dynamics of embolism formation and repair. Oecologia 2001, 126, 182-192. [CrossRef]

13. Ewers, F.W.; Lopez-Portillo, J.; Angeles, G.; Fisher, J.B. Hydraulic conductivity and embolism in the mangrove tree La-guncularia racemosa. Tree Physiol. 2004, 24, 1057-1062. [CrossRef]

14. Jiang, G.; Goodale, U.M.; Liu, Y.; Hao, G.; Cao, K. Salt management strategy defines the stem and leaf hydraulic charac-teristics of six mangrove tree species. Tree Physiol. 2017, 37, 389-401. [CrossRef] [PubMed]

15. Stuart, S.A.; Choat, B.; Martin, K.C.; Holbrook, N.M.; Ball, M.C. The role of freezing in setting the latitudinal limits of mangrove forests. New Phytol. 2007, 173, 576-583. [CrossRef]

16. Sperry, J.S.; Hacke, U.G.; Pittermann, J. Size and function in conifer tracheids and angiosperm vessels. Am. J. Bot. 2006, 93, 1490-1500. [CrossRef] [PubMed]

17. Chave, J.; Coomes, D.; Jansen, S.; Lewis, S.L.; Swenson, N.G.; Zanne, A.E. Towards a worldwide wood economics spec-trum. Ecol. Lett. 2009, 12, 351-366. [CrossRef] [PubMed]

18. Verheyden, A.; De Ridder, F.; Schmitz, N.; Beeckman, H.; Koedam, N. High-resolution time series of vessel density in Kenyan mangrove trees reveal a link with climate. New Phytol. 2005, 167, 425-435. [CrossRef]

19. Gleason, S.M.; Westoby, M.; Jansen, S.; Choat, B.; Hacke, U.G.; Pratt, R.B.; Bhaskar, R.; Brodribb, T.J.; Bucci, S.J.; Cao, K.; et al. Weak tradeoff between xylem safety and xylem-specific hydraulic efficiency across the world's woody plant species. New Phytol. 2016, 209, 123-136. [CrossRef]

20. Rossi, S.; Morin, H.; Deslauriers, A.; Plourde, P. Predicting xylem phenology in black spruce under climate warming. Glob. Chang. Biol. 2011, 17, 614-625. [CrossRef]

21. Gricar, J.; Prislan, P.; Gryc, V.; Vavrcik, H.; de Luis, M.; Cufar, K. Plastic and locally adapted phenology in cambial sea-sonality and production of xylem and phloem cells in Picea abies from temperate environments. Tree Physiol. 2014, 34, 869-881. [CrossRef] 
22. Inoue, S.; Dang, Q.; Man, R.; Tedla, B. Northward migration of trembling aspen will increase growth but reduce resistance to drought-induced xylem cavitation. Botany 2019, 97, 627-638. [CrossRef]

23. García-Cervigón, A.I.; Fajardo, A.; Caetano-Sánchez, C.; Camarero, J.J.; Olano, J.M. Xylem anatomy needs to change, so that conductivity can stay the same: Xylem adjustments across elevation and latitude in Nothofagus pumilio. Ann. Bot. 2020, 125, 1101-1112. [CrossRef]

24. Puchi, P.F.; Castagneri, D.; Rossi, S.; Carrer, M. Wood anatomical traits in black spruce reveal latent water constraints on the boreal forest. Glob. Chang. Biol. 2020, 26, 1767-1777. [CrossRef]

25. Girard, M.; Rossi, S.; Morin, H. Mapping events: Cambium phenology across the latitudinal distribution of black spruce. IAWA J. 2015, 36, 270-285. [CrossRef]

26. Schuldt, B.; Knutzen, F.; Delzon, S.; Jansen, S.; Muller-Haubold, H.; Burlett, R.; Clough, Y.; Leuschner, C. How adaptable is the hydraulic system of European beech in the face of climate change-related precipitation reduction? New Phytol. 2016, 210, 443-458. [CrossRef]

27. Bourne, A.E.; Creek, D.; Peters, J.M.R.; Ellsworth, D.S.; Choat, B. Species climate range influences hydraulic and stomatal traits in Eucalyptus species. Ann. Bot. 2017, 120, 123-133. [CrossRef] [PubMed]

28. Macedo, T.M.; Lima, H.C.D.; de Souza, N.D.; Gonçalves, A.C.; Costa, C.G.; Barros, C.F. Intraspecific variation of Pau-brasilia echinata (Fabaceae) wood along a latitudinal gradient in Brazil. Flora 2019, 258, 151437. [CrossRef]

29. Pfautsch, S.; Harbusch, M.; Wesolowski, A.; Smith, R.; Macfarlane, C.; Tjoelker, M.G.; Reich, P.B.; Adams, M.A. Climate determines vascular traits in the ecologically diverse genus Eucalyptus. Ecol. Lett. 2016, 19, 240-248. [CrossRef] [PubMed]

30. Choat, B.; Sack, L.; Holbrook, N.M. Diversity of hydraulic traits in nine cordia species growing in tropical forests with contrasting precipitation. New Phytol. 2007, 175, 686-698. [CrossRef] [PubMed]

31. Madrid, E.N.; Armitage, A.R.; LÃ Pez-Portillo, J. Avicennia germinans (black mangrove) vessel architecture is linked to chilling and salinity tolerance in the Gulf of Mexico. Front. Plant Sci. 2014, 5, 503. [CrossRef] [PubMed]

32. López, R.; Cano, F.J.; Choat, B.; Cochard, H.; Gil, L. Plasticity in vulnerability to cavitation of Pinus canariensis occurs only at the driest end of an aridity gradient. Front. Plant Sci. 2016, 7, 769. [CrossRef]

33. Lamy, J.; Delzon, S.; Bouche, P.S.; Alia, R.; Vendramin, G.G.; Cochard, H.; Plomion, C. Limited genetic variability and phenotypic plasticity detected for cavitation resistance in a Mediterranean pine. New Phytol. 2014, 201, 874-886. [CrossRef] [PubMed]

34. Zhang, S.; Cao, K.; Fan, Z.; Zhang, J. Potential hydraulic efficiency in angiosperm trees increases with growth-site tem-perature but has no trade-off with mechanical strength. Glob. Ecol. Biogeogr. 2013, 22, 971-981. [CrossRef]

35. Morris, H.; Gillingham, M.A.F.; Plavcová, L.; Gleason, S.M.; Olson, M.E.; Coomes, D.A.; Fichtler, E.; Klepsch, M.M.; Mar-tínezCabrera, H.I.; McGlinn, D.J.; et al. Vessel diameter is related to amount and spatial arrangement of axial pa-renchyma in woody angiosperms. Plant Cell Environ. 2018, 41, 245-260. [CrossRef] [PubMed]

36. He, P.; Gleason, S.M.; Wright, I.J.; Weng, E.; Liu, H.; Zhu, S.; Lu, M.; Luo, Q.; Li, R.; Wu, G.; et al. Growing-season tem-perature and precipitation are independent drivers of global variation in xylem hydraulic conductivity. Glob. Chang. Biol. 2020, 26, 1833-1841. [CrossRef] [PubMed]

37. Li, X.; Blackman, C.J.; Choat, B.; Duursma, R.A.; Rymer, P.D.; Medlyn, B.E.; Tissue, D.T. Tree hydraulic traits are coor-dinated and strongly linked to climate-of-origin across a rainfall gradient. Plant Cell Environ. 2018, 41, 646-660. [CrossRef]

38. Wu, Y.; Ricklefs, R.E.; Huang, Z.; Zan, Q.; Yu, S. Winter temperature structures mangrove species distributions and as-semblage composition in China. Glob. Ecol. Biogeogr. 2018, 27, 1492-1506. [CrossRef]

39. Gilman, E.L.; Ellison, J.; Duke, N.C.; Field, C. Threats to mangroves from climate change and adaptation options: A review. Aquat. Bot. 2008, 89, 237-250. [CrossRef]

40. Duke, N.C.; Kovacs, J.M.; Griffiths, A.D.; Preece, L.; Hill, D.J.E.; van Oosterzee, P.; Mackenzie, J.; Morning, H.S.; Burrows, D. Large-scale dieback of mangroves in Australia's Gulf of Carpentaria: A severe ecosystem response, coincidental with an unu-sually extreme weather event. Mar. Freshw. Res. 2017, 68, 1816-1829. [CrossRef]

41. Giri, C.; Ochieng, E.; Tieszen, L.L.; Zhu, Z.; Singh, A.; Loveland, T.; Masek, J.; Duke, N. Status and distribution of mangrove forests of the world using earth observation satellite data. Glob. Ecol. Biogeogr. 2011, 20, 154-159. [CrossRef]

42. Lovelock, C.E.; Feller, I.C.; Reef, R.; Hickey, S.; Ball, M.C. Mangrove dieback during fluctuating sea levels. Sci. Rep. 2017, 7, 1680. [CrossRef]

43. Duke, N.C. Mangrove Floristics and Biogeography. In Tropical Mangrove Ecosystems Robertson, A.I.; Alongi, D.M., Ed.; American Geophysical Union: Washington, DC, USA, 1992; Volume 41, pp. 63-100.

44. Marine Science Australia. Available online: https://www.ausmarinescience.com/marine-science-basics/oceanography-ofaustralia/ (accessed on 28 December 2020).

45. Sea Surface Salinity Remote Sensing Project. Available online: http:/ /www.salinityremotesensing.ifremer.fr/sea-surface-salinity / salinity-distribution-at-the-ocean-surface (accessed on 28 December 2020).

46. WorldClim. Available online: https:/ / www.worldclim.org/ (accessed on 28 May 2020).

47. Whitley, R.; Evans, B.; Pauwels, J.; Hutchinson, M.; Xu, T.; Wang, H. 2014. Potential evapotranspiration (approximated), an-nual precipitation: eMAST-R-Package 2.0, 0.01 degree, Australian coverage, 1970-2012, Macquarie University, Sydney, Australia. Obtained from http:/ / dap.nci.org.au, made available by the Ecosystem Modelling and Scaling Infrastructure (eMAST, http://www.emast.org.au). Facility of the Terrestrial Ecosystem Research Network (TERN, http://www.tern.org.au) (accessed on 5 May 2016). 
48. Yang, J.; Medlyn, B.E.; De Kauwe, M.G.; Duursma, R.A. Applying the concept of ecohydrological equilibrium to predict steady state leaf area index. J. Adv. Model. Earth Syst. 2018, 10, 1740-1758. [CrossRef]

49. Bureau of Meteorology. Available online: http:/ / www.bom.gov.au (accessed on 19 May 2020).

50. Ewers, F.W.; Fisher, J.B. Techniques for measuring vessel lengths and diameters in stems of woody plants. Am. J. Bot. 1989, 76, 645-656. [CrossRef]

51. Cohen, S. Air method measurements of apple vessel length distributions with improved apparatus and theory. J. Exp. Bot. 2003, 54, 1889-1897. [CrossRef] [PubMed]

52. Scholz, A.; Klepsch, M.; Karimi, Z.; Jansen, S. How to quantify conduits in wood? Front. Plant Sci. 2013, 4, 56. [CrossRef] [PubMed]

53. López-Portillo, J.; Ewers, F.W.; Angeles, G. Sap salinity effects on xylem conductivity in two mangrove species. Plant Cell Environ. 2005, 28, 1285-1292. [CrossRef]

54. Sperry, J.S.; Donnelly, J.R.; Tyree, M.T. A method for measuring hydraulic conductivity and embolism in xylem. Plant Cell Environ. 1988, 11, 35-40. [CrossRef]

55. Wheeler, J.K.; Huggett, B.A.; Tofte, A.N.; Rockwell, F.E.; Holbrook, N.M. Cutting xylem under tension or supersaturated with gas can generate PLC and the appearance of rapid recovery from embolism. Plant Cell Environ. 2013, 36, 1938-1949. [CrossRef] [PubMed]

56. Torres-Ruiz, J.M.; Jansen, S.; Choat, B.; McElrone, A.J.; Cochard, H.; Brodribb, T.J.; Badel, E.; Burlett, R.; Bouche, P.S.; Brodersen, C.R.; et al. Direct X-ray microtomography observation confirms the induction of embolism upon xylem cutting under tension. Plant Physiol. 2015, 167, 40-43. [CrossRef]

57. Choat, B.; Drayton, W.M.; Brodersen, C.; Matthews, M.A.; Shackel, K.A.; Wada, H.; McElrone, A.J. Measurement of vulnerability to water stress-induced cavitation in grapevine: A comparison of four techniques applied to a long-vesseled species. Plant Cell Environ. 2010, 33, 1502-1512. [CrossRef] [PubMed]

58. Cochard, H.; Badel, E.; Herbette, S.; Delzon, S.; Choat, B.; Jansen, S. Methods for measuring plant vulnerability to cavi-tation: A critical review. J. Exp. Bot. 2013, 64, 4779-4791. [CrossRef]

59. Melcher, P.; Warchocki, S. The impact of xylem wounding on the measure of stem hydraulic resistance. In Botanical Society of America; Providence, RI, USA, 2010.

60. Melcher, P.J.; Michele Holbrook, N.; Burns, M.J.; Zwieniecki, M.A.; Cobb, A.R.; Brodribb, T.J.; Choat, B.; Sack, L. Meas-urements of stem xylem hydraulic conductivity in the laboratory and field. Methods Ecol. Evol. 2012, 3, 685-694. [CrossRef]

61. Chave, J.; Muller-Landau, H.C.; Baker, T.R.; Easdale, T.A.; ter Steege, H.; Webb, C.O. Regional and phylogenetic variation of wood density across 2456 Neotropical tree species. Ecol. Appl. 2006, 16, 2356-2367. [CrossRef]

62. William, R.L.A.; Klein, T.; Bartlett, M.; Sack, L.; Adam, F.A.P.; Choat, B.; Jansen, S. Meta-analysis reveals that hydraulic traits explain cross-species patterns of drought-induced tree mortality across the globe. Proc. Natl. Acad. Sci. USA 2016, 113, 5024-5029. [CrossRef]

63. Tyree, M.T.; Zimmermann, M.H. Xylem Structure and the Ascent of Sap, 2nd ed.; Springer: Berlin, Heidelberg, Germany, 2002; p. 283.

64. Lens, F.; Sperry, J.S.; Christman, M.A.; Choat, B.; Rabaey, D.; Jansen, S. Testing hypotheses that link wood anatomy to cavitation resistance and hydraulic conductivity in the genus Acer. New Phytol. 2011, 190, 709-723. [CrossRef]

65. Duursma, R.; Choat, B. fitplc-An R package to fit hydraulic vulnerability curves. J. Plant Hydraul. 2017, 4, 002. [CrossRef]

66. Tyree, M.T.; Sperry, J.S. Vulnerability of xylem to cavitation and embolism. Annu. Rev. Plant Physiol. Plant Molec. Biol. 1989, 40, 19-36. [CrossRef]

67. Maherali, H.; DeLucia, E.H. Xylem conductivity and vulnerability to cavitation of ponderosa pine growing in contrasting climates. Tree Physiol. 2000, 20, 859-867. [CrossRef] [PubMed]

68. Li, S.; Lens, F.; Espino, S.; Karimi, Z.; Klepsch, M.; Schenk, H.J.; Schmitt, M.; Schuldt, B.; Jansen, S. Intervessel pit membrane thickness as a key determinant of embolism resistance in angiosperm xylem. IAWA J. 2016, 37, 152-171. [CrossRef]

69. Hacke, U.G.; Sperry, J.S.; Pockman, W.T.; Davis, S.D.; McCulloh, K.A. Trends in wood density and structure are linked to prevention of xylem implosion by negative pressure. Oecologia 2001, 126, 457-461. [CrossRef] [PubMed]

70. Janssen, T.A.J.; Hölttä, T.; Fleischer, K.; Naudts, K.; Dolman, H. Wood allocation trade-offs between fiber wall, fiber lumen, and axial parenchyma drive drought resistance in neotropical trees. Plant Cell Environ. 2020, 43, 965-980. [CrossRef] [PubMed]

71. Hoeber, S.; Leuschner, C.; Köhler, L.; Arias-Aguilar, D.; Schuldt, B. The importance of hydraulic conductivity and wood density to growth performance in eight tree species from a tropical semi-dry climate. For. Ecol. Manag. 2014, 330, 126-136. [CrossRef]

72. Schumann, K.; Leuschner, C.; Schuldt, B. Xylem hydraulic safety and efficiency in relation to leaf and wood traits in three temperate Acer species differing in habitat preferences. Trees 2019, 33, 1475-1490. [CrossRef]

73. Schmitz, N.; Verheyden, A.; Beeckman, H.; Kairo, J.G.; Koedam, N. Influence of a salinity gradient on the vessel characters of the mangrove species Rhizophora mucronata. Ann. Bot. 2006, 98, 1321-1330. [CrossRef]

74. Liu, H.; Ye, Q.; Gleason, S.M.; He, P.; Yin, D. Weak tradeoff between xylem hydraulic efficiency and safety: Climatic sea-sonality matters. New Phytol. 2021, 229, 1440-1452. [CrossRef]

75. Gleason, S.M.; Westoby, M.; Jansen, S.; Choat, B.; Brodribb, T.J.; Cochard, H.; Delzon, S.; Hacke, U.G.; Jacobsen, A.L.; Johnson, D.M.; et al. On research priorities to advance understanding of the safety-efficiency tradeoff in xylem. New Phytol. 2016, 211, 1156-1158. [CrossRef] 
76. Lovelock, C.E.; Krauss, K.W.; Osland, M.J.; Reef, R.; Ball, M.C. The physiology of mangrove trees with changing climate. In Tropical Tree Physiology; Goldstein, G., Santiago, L.S., Eds.; Springer: Cham, Switzerland, 2016; pp. 149-179.

77. Feller, I.C.; Lovelock, C.E.; Berger, U.; McKee, K.L.; Joye, S.B.; Ball, M.C. Biocomplexity in Mangrove Ecosystems. Annu. Rev. Mar. Sci. 2010, 2, 395-417. [CrossRef] [PubMed]

78. Robert, E.M.R.; Koedam, N.; Beeckman, H.; Schmitz, N. A safe hydraulic architecture as wood anatomical explanation for the difference in distribution of the mangroves Avicennia and Rhizophora. Funct. Ecol. 2009, 23, 649-657. [CrossRef]

79. Schmitz, N.; Robert, E.M.R.; Verheyden, A.; Kairo, J.G.; Beeckman, H.; Koedam, N. A patchy growth via successive and simulta-neous cambia: Key to success of the most widespread mangrove species Avicennia marina? Ann. Bot. 2007, 101, 49-58. [CrossRef]

80. Robert, E.M.R.; Jambia, A.H.; Schmitz, N.; De Ryck, D.J.R.; De Mey, J.; Kairo, J.G.; Dahdouh-Guebas, F.; Beeckman, H.; Koedam, N. How to catch the patch? A dendrometer study of the radial increment through successive cambia in the mangrove Avicennia. Ann. Bot. 2014, 113, 741-752. [CrossRef]

81. Carlquist, S. Successive cambia revisited: Ontogeny, histology, diversity, and functional significance. J. Torrey Bot. Soc. 2007, 134, 301-332. [CrossRef]

82. Robert, E.M.R.; Schmitz, N.; Boeren, I.; Driessens, T.; Herremans, K.; De Mey, J.; Van de Casteele, E.; Beeckman, H.; Koedam, N. Successive cambia: A developmental oddity or an adaptive structure? PLoS ONE 2011, 6, e16558. [CrossRef]

83. Santini, N.S.; Schmitz, N.; Lovelock, C.E. Variation in wood density and anatomy in a widespread mangrove species. Trees 2012, 26, 1555-1563. [CrossRef]

84. Hacke, U.G.; Sperry, J.S.; Wheeler, J.K.; Castro, L. Scaling of angiosperm xylem structure with safety and efficiency. Tree Physiol. 2006, 26, 689-701. [CrossRef]

85. Hacke, U.G.; Sperry, J.S. Functional and ecological xylem anatomy. Perspect. Plant Ecol. Evol. Syst. 2001, 4, 97-115. [CrossRef]

86. Choat, B.; Cobb, A.R.; Jansen, S. Structure and function of bordered pits: New discoveries and impacts on whole-plant hydraulic function. New Phytol. 2008, 177, 608-626. [CrossRef] [PubMed]

87. Asbridge, E.; Lucas, R.; Accad, A.; Dowling, R. Mangrove response to environmental changes predicted under varying climates: Case studies from Australia. Curr. For. Rep. 2015, 1, 178-194. [CrossRef]

88. Santiago, L.S.; Goldstein, G.; Meinzer, F.C.; Fisher, J.B.; Machado, K.; Woodruff, D.; Jones, T. Leaf photosynthetic traits scale with hydraulic conductivity and wood density in Panamanian forest canopy trees. Oecologia 2004, 140, 543-550. [CrossRef] [PubMed]

89. Fazlioglu, F.; Wan, J.S.H.; Chen, L. Latitudinal shifts in mangrove species worldwide: Evidence from historical occurrence records. Hydrobiologia 2020, 847, 4111-4123. [CrossRef]

90. Cavanaugh, K.C.; Kellner, J.R.; Forde, A.J.; Gruner, D.S.; Parker, J.D.; Rodriguez, W.; Feller, I.C. Poleward expansion of mangroves is a threshold response to decreased frequency of extreme cold events. Proc. Natl. Acad. Sci. USA 2014, 111, 723-727. [CrossRef]

91. Dai, A. Increasing drought under global warming in observations and models. Nat. Clim. Chang. 2013, 3, 52-58. [CrossRef]

92. Feher, L.C.; Osland, M.J.; Griffith, K.T.; Grace, J.B.; Howard, R.J.; Stagg, C.L.; Enwright, N.M.; Krauss, K.W.; Gabler, C.A.; Day, R.H.; et al. Linear and nonlinear effects of temperature and precipitation on ecosystem properties in tidal saline wetlands. Ecosphere 2017, 8, e01956. [CrossRef]

93. Osland, M.J.; Feher, L.C.; Griffith, K.T.; Cavanaugh, K.C.; Enwright, N.M.; Day, R.H.; Stagg, C.L.; Krauss, K.W.; Howard, R.J.; Grace, J.B.; et al. Climatic controls on the global distribution, abundance, and species richness of mangrove forests. Ecol. Monogr. 2017, 87, 341-359. [CrossRef]

94. Gabler, C.A.; Osland, M.J.; Grace, J.B.; Stagg, C.L.; Day, R.H.; Hartley, S.B.; Enwright, N.M.; From, A.S.; McCoy, M.L.; McLeod, J.L. Macroclimatic change expected to transform coastal wetland ecosystems this century. Nat. Clim. Chang. 2017, 7, 142-147. [CrossRef]

95. Steppe, K.; Vandegehuchte, M.W.; Van de Wal, B.A.E.; Hoste, P.; Guyot, A.; Lovelock, C.E.; Lockington, D.A. Direct uptake of canopy rainwater causes turgor-driven growth spurts in the mangrove Avicennia marina. Tree Physiol. 2018, 38, 979-991. [CrossRef] [PubMed] 